\title{
Expression of the H-ras Oncogene Induces Potassium Conductance and Neuron-specific Potassium Channel mRNAs in the AtT20 Cell Line
}

\author{
Lucinda M. Hemmick, ${ }^{a}$ Teresa M. Perney, Robert E. Flamm, Leonard K. Kaczmarek, and Neal C. Birnberg \\ Department of Pharmacology, Yale University School of Medicine, New Haven, Connecticut 06510
}

\begin{abstract}
Expression of the EJ-ras oncogene in the AtT20 cell line results in several changes in their properties that correspond to a switch of these anterior pituitary-derived cells to a more neuronlike phenotype. The width of action potentials following transfection with ras is reduced 20 -fold from over 200 msec in control AtT20 cells to less than $10 \mathrm{msec}$ in rastransfected cells. This is associated with a two- to threefold increase in the density of voltage-dependent potassium currents. In addition, the rate of inactivation of these currents is decreased approximately twofold in ras-transfected cells. At least part of the change in potassium current may be due to differential expression of potassium channel mRNAs. In the ras-transfected cells, mRNA species were detected using a probe for the voltage-dependent potassium channels, $\mathrm{Kv4}$, a species that appears to be uniquely expressed in the nervous system, and NGK2, an alternatively spliced product transcribed from the same gene. These mRNAs are not detected in control AtT20 cells. The results suggest that the ras protein modulates the phenotype of excitable cells by influencing the expression of specific potassium channels and thereby altering the density and types of channels in the plasma membrane.
\end{abstract}

The ras-family of protooncogenes encodes a set of $21 \mathrm{kDa}$ proteins ( $\mathrm{p} 21^{\mathrm{ras}}$ ) and is a member of a GTPase superfamily of genes whose products bind and hydrolyze guanine nucleotides (for a recent review, see Bourne et al., 1990). One interesting aspect of these proteins is that they are highly expressed in neurons and neurosecretory cells (Mizoguchi et al., 1989). By analogy with other, better understood, guanine nucleotide-binding proteins that link neurotransmitter and hormone receptors to second messenger pathways, it has been suggested that the ras proteins participate in as yet uncharacterized signal transduction pathways (Barbacid, 1987).

The high levels of ras expression in the nervous system and other excitable tissues suggest that $\mathrm{p} 21^{\text {ras }}$ could be an important component of pathways that regulate the long-term excitability

\footnotetext{
Received Sept. 25, 1991; revised Nov. 27, 1991; accepted Dec. 11, 1991.

This work was supported by a PHS training grant to L.M.H., a PHS fellowship to T.M.P., a grant from Bristol-Myers Squibb to N.C.B., and NIH Grant HL38156 to L.K.K. We thank Dr. Edwin Levitan for helpful discussions and Mr. Carl Richmond for help in the preparation of the manuscript.

Correspondence should be addressed to Dr. Neal C. Birnberg, Department of Pharmacology, Yale University School of Medicine, 333 Cedar Street, New Haven, CT 06510.

a Present address: Department of Pediatrics, School of Medicine, SUNY at Stony Brook, Stony Brook, NY 11794.

Copyright (C 1992 Society for Neuroscience $0270-6474 / 92 / 122007-08 \$ 05.00 / 0$
}

of neurons and other cells. To test this possibility, we have transfected the human H-ras oncogene EJ-ras (Shih and Weinberg, 1982) into the mouse neurosecretory line AtT20. The EJras oncogene encodes a protein that differs from the normal ras protein by one amino acid. This lowers the intrinsic rate of GTP hydrolysis by $\mathrm{p} 21^{\text {ras }}$ and also eliminates its sensitivity to stimulation by GAP, the GTPase activator protein for $\mathrm{p} 21^{\text {ras }}$ (Vogel et al., 1988). This mutation therefore increases the fraction of time spent by the protein in the active, GTP-bound state, and by analogy with other GTP-binding proteins, fixes the protein in its active "signaling" mode.

The AtT20 cell line is derived from a pituitary tumor that secretes ACTH and $\beta$-endorphin. It has long served as a model system for the study of hormonal regulation of neuropeptide synthesis, posttranslational processing, and release (Herbert et al., 1978; Roberts et al., 1978; Burgess and Kelley, 1987). In addition, AtT20 cells are excitable and the ionic currents that underlie their electrical behavior have been partially characterized (Suprenant, 1982; Adler et al., 1983; Flamm et al., 1990). We have found that transfection of these cells with the H-ras oncogene induces several changes in their excitability. These include a decrease in the width of spontaneous and evoked action potentials and a change in the amplitude and kinetics of their voltage-dependent potassium currents. These changes are associated with the induction of mRNA species that encode components of voltage-activated potassium channels specific to the nervous system.

\section{Materials and Methods}

Cell culture. AtT20 cells, both normal and ras transformed, were maintained in Dulbecco's modified Eagle's medium supplemented with $10 \%$ fetal bovine serum or $10 \%$ horse serum and $2.5 \%$ fetal bovine serum. ras-transformed AtT20 cells were maintained in selection with $400 \mu \mathrm{g}$ / $\mathrm{ml} \mathrm{G418.} \mathrm{Details} \mathrm{of} \mathrm{the} \mathrm{transfection} \mathrm{by} \mathrm{EJ-ras} \mathrm{are} \mathrm{described} \mathrm{elsewhere}$ (Birnberg et al., 1992).

Electrophysiology. Whole-cell voltage-clamp recordings were made at $21^{\circ} \mathrm{C}$ using an L/M EPC-7 patch clamp (List Electronics, DarmstadtEberstadt). Electrodes had a resistance of $1.5-2.5 \mathrm{M} \Omega$ after fire polishing. The tips of patch electrodes were dipped in Sigmacote (Sigma Chemical Co., St. Louis, MO) to reduce electrode capacitance prior to use. The whole-cell patch configuration was attained using either standard techniques (Hamill et al., 1981) or the perforated patch technique (Horn and Marty, 1986). Cell capacitance and series resistance were electronically compensated using the compensation controls of an EPC-7 patch clamp, which were also used to estimate cell capacitance. Data were collected using a computer (Indec Systems, Inc., Sunnyvale, CA). The external saline contained (in $\mathrm{mM}$ ) $150 \mathrm{~N}$-methyl glucamine, $5.4 \mathrm{KCl}$, 0.1 EGTA, $10 \mathrm{HEPES}$ acid, $2.8 \mathrm{MgCl}_{2}$, and 20 glucose, $\mathrm{pH} 7.4$ (with $\mathrm{HCl}$ ). The dialyzed cell whole-cell patch experiments used an internal solution containing (in mM) $70 \mathrm{KCl}, 70$ potassium aspartate, $1 \mathrm{CaCl}_{2}$, 11 EGTA, 10 HEPES acid, and $5 \mathrm{Mg}$-ATP. The electrode solution for 
A

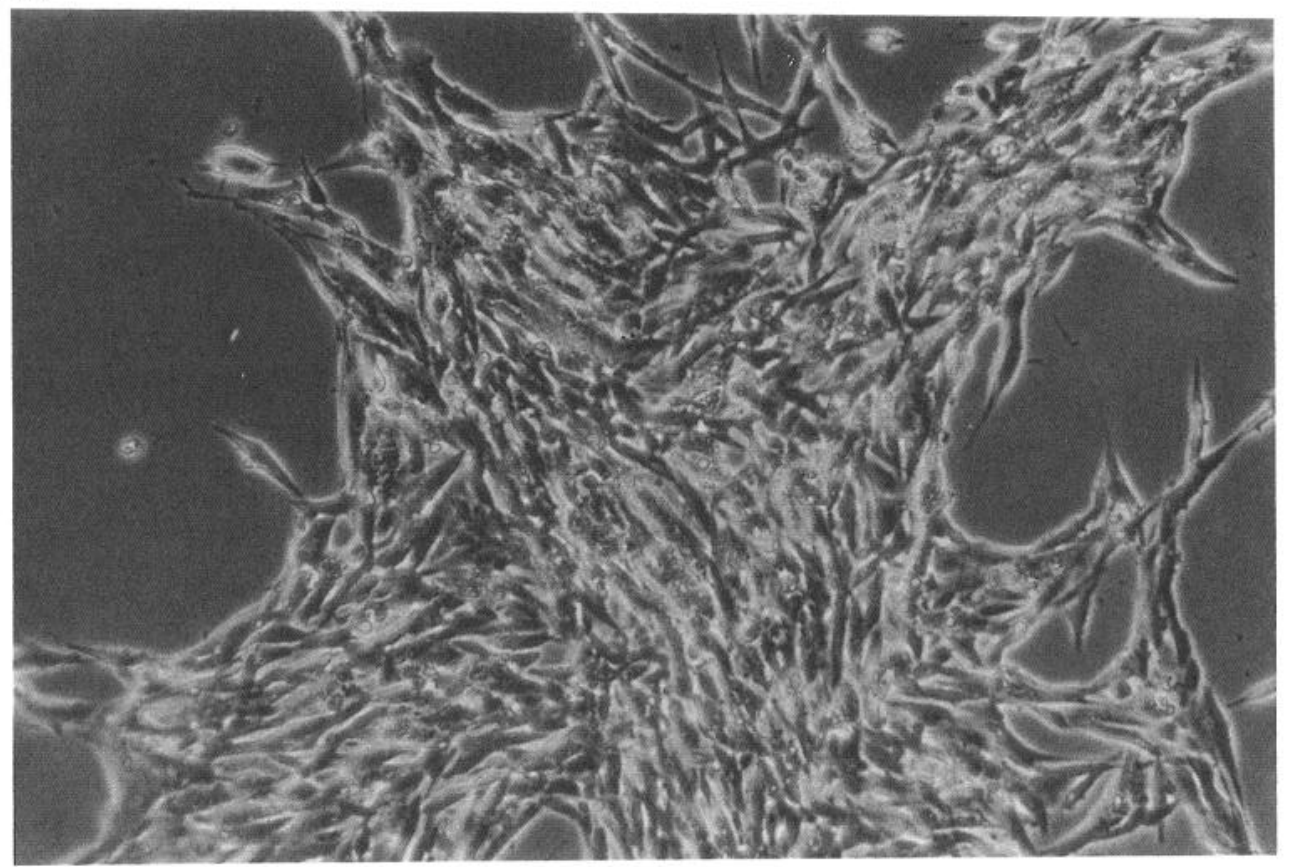

B

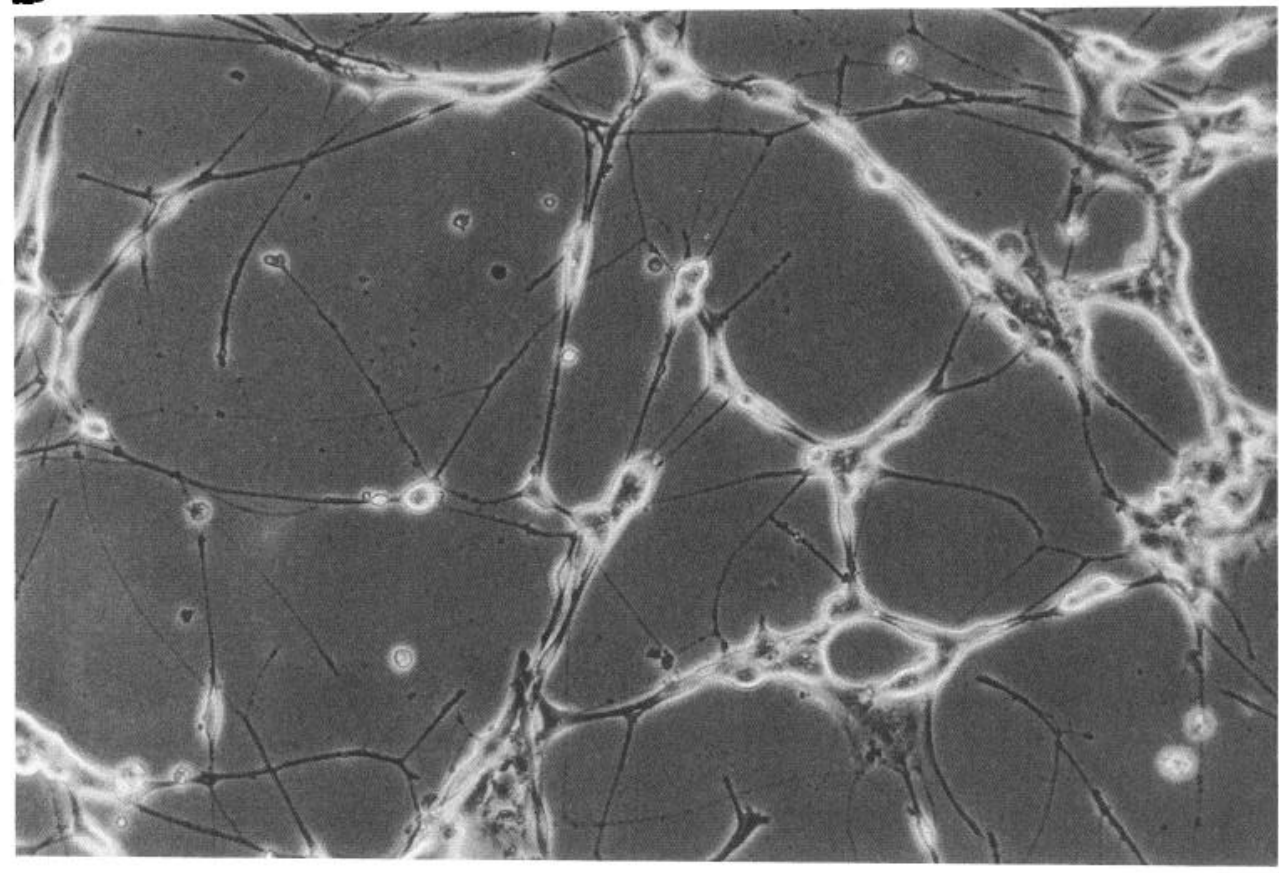

Figure 1. Phase-contrast photomicrograph of normal AtT20 cells $(A)$ and EJ-ras transfected clone R1 $(B)$.

perforated patch experiments contained (in $\mathrm{mM}$ ) $120 \mathrm{~K}_{2} \mathrm{SO}_{4}, 16 \mathrm{KCl}, 5$ $\mathrm{MgSO}_{4}$, and $10 \mathrm{Na}-\mathrm{HEPES}$.

Preparation of RNA and Northern blots. RNA was prepared by acid guanidinium thiocyanate-phenol-chloroform extraction, as described by Chomczynski and Sacchi (1987). PolyA RNA was obtained by elution from an oligo(dT)-cellulose column. RNA was fractionated on 0.66 M formaldehyde $1 \%$ agarose (w/v) gels in $1 \times$ morpholinepropanesulfonic acid buffer (Davis et al., 1986) with recirculation. Gels were transferred to GeneScreen Plus membranes (Du Pont New England Nuclear) in $10 \times$ saline-sodium citrate (SSC; $1.5 \mathrm{M} \mathrm{NaCl}, 0.15 \mathrm{M} \mathrm{Na}$ citrate).
Membranes were then baked $2 \mathrm{hr}$ at $80^{\circ} \mathrm{C}$ and prehybridized in $40 \%$ formamide, $10 \%$ dextran sulfate $(\mathrm{w} / \mathrm{v}), 4 \times \mathrm{SSC}, 7 \mathrm{~mm}$ Tris, $\mathrm{pH} 7.6,1 \times$ Denhardt's solution, $1 \%$ SDS (w/v), and $200 \mu \mathrm{g} / \mathrm{ml}$ denatured salmon sperm DNA, at $44^{\circ} \mathrm{C}$ for $>1 \mathrm{hr}$. A DNA fragment subcloned in pGEM-A (Swanson et al., 1990) corresponding to positions 1-1793, relative to the translation initiation codon (Luneau et al., 1991), produced by digestion with EcoRI and HindIII, was gel purified and labeled by random primer extension with Escherichia coli DNA polymerase I large fragment in the presence of $\alpha-{ }^{32} \mathrm{P}-\mathrm{dCTP}(3000 \mathrm{Ci} / \mathrm{mmol}$; Amersham). The sequence of the cDNA probe is unique to the $\mathrm{Kv} 4$ gene according to a 
search of the GenBank database. This radiolabeled fragment was used as the probe for the Kv4 Northern blot. The cDNA probe for Kvl was from positions -221 to 1908 relative to the start of translation (Swanson et al., 1990). The probe for drk1, a 750 base pair cDNA fragment corresponding to -98 to +633 relative to the initiation codon (Frech et al., 1989), was a gift from J. Trimmer. Hybridization was carried out at $44^{\circ} \mathrm{C}$ for $16 \mathrm{hr}$ in prehybridization solution with $100 \mu \mathrm{g} / \mathrm{ml}$ denatured salmon sperm DNA, and $2 \times 10^{6} \mathrm{cpm} / \mathrm{ml}$ of radiolabeled probe. The blot was washed in $2 \times \mathrm{SSC}, 0.1 \%$ SDS twice at room temperature for $15 \mathrm{~min}$ followed by a high-stringency wash for $30 \mathrm{~min}$ in $0.1 \times \mathrm{SSC}$, $1 \% \mathrm{SDS}$ at $44^{\circ} \mathrm{C}$. Autoradiography was performed using Kodak X-Omat AR x-ray film to visualize the hybridized probe.

Ribonuclease protection assay. Total RNA was used in the ribonuclease protection assay as described by Ausubel et al. (1990). An $\alpha^{-32} \mathbf{P}$ CTP-labeled antisense RNA probe (413 nucleotides long) derived from the $3^{\prime}$ end of the same Kv4 cDNA clone used in the Northern blot analysis was transcribed with SP6 RNA polymerase after linearization with PvulI. This probe is complementary to the last 398 nucleotides of the 3 ' end of $\mathrm{Kv} 4$ and extends upstream 108 nucleotides past the splice junction for NGK2 (Luneau et al., 1991). Thus, a 108 base pair stretch of the probe is common to both Kv4 and NGK2 RNAs. An excess of the ${ }^{32} \mathrm{P}$-labeled probe was hybridized overnight with total and polyA RNAs in $80 \%$ formamide at $45^{\circ} \mathrm{C}$. Single-stranded RNA was then digested by the addition of RNases $A$ and T1. After proteinase $\mathrm{K}$ treatment and phenol-chloroform extraction, the samples were precipitated with ethanol and then separated on a $4 \%$ polyacrylamide, $7 \mathrm{M}$ urea sequencing gel. The protected bands were visualized by autoradiography.

\section{Results}

ras induces changes in electrical excitability

Cells of the AtT20/D16v subline were cotransfected with pEJ6.6, the cloned human H-ras oncogene (Shih and Weinberg, 1982), and the selectable marker pRSVNeo. A small number of G418resistant colonies (three from $6 \times 10^{6}$ cells) survived selection. In contrast to normal AtT20 cells, which have a spindlelike morphology, the transfected colonies had a neuronal-like morphology with larger, typically bipolar, cell bodies and with several long neurites. Photomicrographs of normal AtT20 cells and ras-transfected clone $\mathrm{R} 1$ used in these studies are presented in Figure 1. This clone expressed the EJ-ras allele containing a point mutation at codon 12 and had elevated levels of the $221^{\text {ras }}$ protein (Birnberg et al., 1992). Details of the transfection, screening, and selection of EJ-ras transformed AtT20 cells is described elsewhere (Birnberg et al., 1992).

Recordings of electrical activity of control At T20 cells, made using either the whole-cell patch configuration (Hamill et al., 1981) or the perforaled patch technique (Horn and Marty, 1986), showed a pattern of electrical activity that closely matched that previously reported using microelectrode recording (Adler et al., 1983). These cells generate spontaneous action potentials at a frequency of $\sim 0.4-2.0 \mathrm{~Hz}$ (Fig. 2, upper trace). The mean membrane potential measured between action potentials using the whole-cell patch configuration was $-54.6 \pm 3.5$ (SE) $\mathrm{mV}$ $(n=10)$. The action potentials are typical of neuroendocrine cells, having widths of $200-400 \mathrm{msec}$ (Fig. 2, upper trace). The mean membrane potential of ras-transfected cells, $-62.0 \pm 1.8$ $\mathrm{mV}(n=17)$, was not very different from that of the control AtT20 cells. In all the ras-transfected cells, however, the duration of action potentials was substantially reduced relative to the control cells, typically lasting only about $10 \mathrm{msec}$ or less (Fig. 2).

The changes in the action potentials were observed in all three ras-transfected clones and suggest one or more voltage-dependent ion currents expressed in ras oncogene-transfected AtT20 cells differ from those in control AtT20 cells. Further, in the majority of ras-transfected cells recorded using the conventional

\section{Control AtT-20}
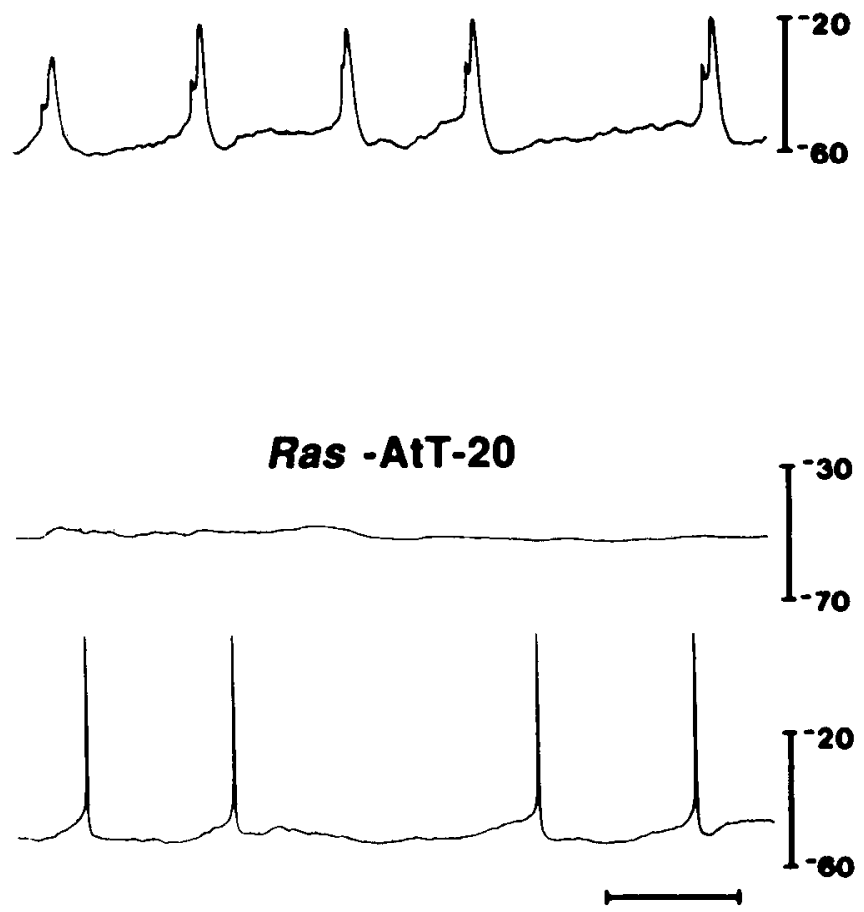

Figure 2. Action potentials recorded in a control pRSVneo-transfected AtT 20 cell and ras-transfected clone R1. Action potentials did not occur spontaneously in this ras-transfected cell (middle trace) but could be evoked by a sustained depolarizing current (bottom trace). Horizontal calibration, $1 \mathrm{sec}$.

patch-clamp technique (15 of 17), repetitive activity was not spontaneous (Fig. 2, middle trace) but could only be evoked by the application of a sustained depolarizing current (Fig. 2, lower trace). In four of four ras-transfected cells recorded with the less invasive perforated patch technique, however, spontaneous firing of normal action potentials such as in Figure 2 (bottom trace) was observed in the absence of applied current. We speculate that the perforated patch technique may preserve any diffusible components that affect spontaneous activity to a greater extent than conventional whole-cell dialysis.

Because voltage-dependent potassium currents are an important determinant of action potential width, we analyzed these currents in detail in normal AtT20 cells and in one of the rastransfected AtT 20 clones (R1). Figure $3 A$ shows whole-cell patchclamp recordings of outward currents from a normal cell on the left and a ras-transfected AtT20 cell on the right. Cells were held at $-90 \mathrm{mV}$ and stepped from $-40 \mathrm{mV}$ to $+60 \mathrm{mV}$ at 5 $\mathrm{mV}$ increments (10 mV increments are shown). The currents from normal and ras-transfected cells have a number of common characteristics. First, these currents are abolished by replacement of intracellular potassium with $\mathrm{Cs}^{+}$, and both currents exhibit similar sensitivities to the potassium channel blocker tetraethylammonium $\mathrm{Cl}$, being blocked to about $90 \%$ at $10 \mathrm{mM}$, suggesting that the currents are carried by potassium ions. Second, the voltage dependence of activation for each is similar, with significant activation occurring at steps more positive than $-10 \mathrm{mV}$ (Fig. 3B). Third, both currents undergo partial inactivation in response to test potentials greater than $+20 \mathrm{mV}$. Although the outward currents in control and ras-transfected AtT20 cells are qualitatively similar, they differ in two impor- 
A

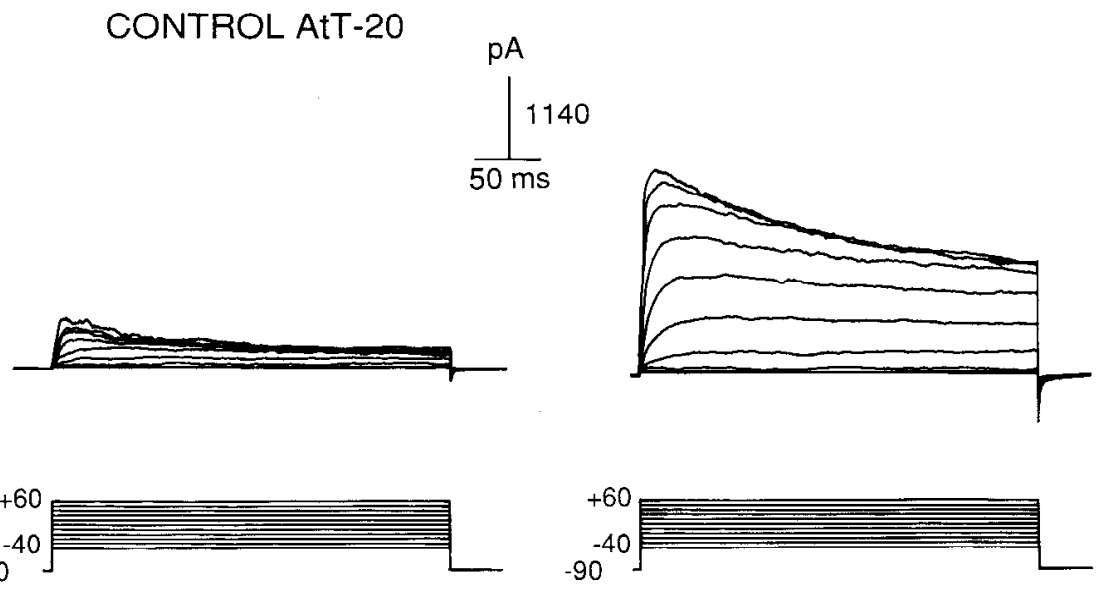

Figure 3. Voltage-dependent potassium current recorded under whole-cell voltage clamp in untransfected AtT20 cells and in EJ-ras-transfected clone R1 $(A)$, and their corresponding $I-V$ curves $(B)$. The current generated in the $\mathrm{R} 1$ cell was about five times larger than the normal AtT20 cell current. Both cells exhibit inactivation at depolarized voltage steps. The $I-V$ curves $(B)$ show the peak current and current at the end of a $300 \mathrm{msec}$ pulse for both cclls. At depolarized steps, the differential between the peak and final currents becomes evident at voltage steps to potentials more positive than $+10 \mathrm{mV}$.

B

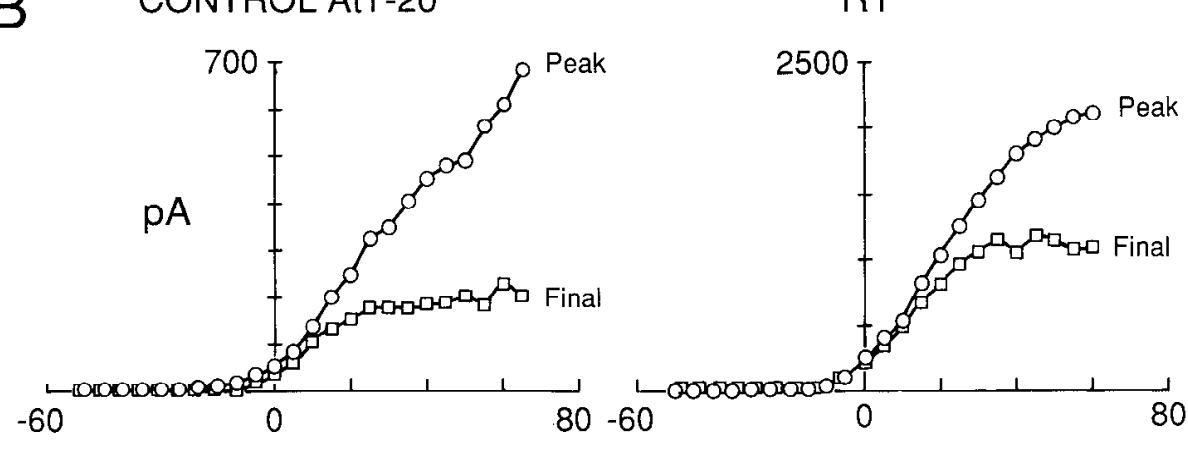

R1

$\mathrm{mV}$

tant respects. The potassium current measured in ras-transfected cells is approximately five times greater than that in control cells (Fig. 3A, Table 1). Note the differences in the current scales in the current-voltage $(I-V)$ relationships (Fig. $3 B$ ). In part, this could reflect the increased size of the ras-transfected cells. However, when currents were normalized for total plasma membrane surface area, using cell capacitance as a measure of surface area, it was found that the current density is at least two times greater in the ras-transfected cells than in control AtT20 cells $(p<0.0005$; Table 1$)$. This difference was observed for both the peak current and for the partially inactivated current at the end of a $300 \mathrm{msec}$ pulse to $+50 \mathrm{mV}$.

Normal and ras-transfected cell lines also differ in the amount and rate of inactivation of their outward currents. The falling

Table 1. Differences in properties of the voltage-dependent potassium current in wild-type and ras tranfected AtT20 cells

\begin{tabular}{|c|c|c|c|c|c|c|}
\hline \multirow[b]{2}{*}{ Cell } & \multirow{2}{*}{$\begin{array}{l}\text { Current } \\
(\mathrm{pA})\end{array}$} & \multicolumn{2}{|c|}{$\begin{array}{l}\text { Current density } \\
(\mathrm{pA} / \mathrm{pF})\end{array}$} & \multirow{2}{*}{$\begin{array}{l}\text { Reduction } \\
\text { of current } \\
\text { during } \\
300 \mathrm{msec} \\
\text { pulse }(\%)\end{array}$} & \multirow{2}{*}{$\begin{array}{l}\text { Inactivation } \\
\text { time } \\
\text { constant } \\
\text { (msec) }\end{array}$} & \multirow{2}{*}{$\begin{array}{l}\text { Capaci- } \\
\text { tance } \\
(\mathrm{pF})\end{array}$} \\
\hline & & Peak & Final $^{a}$ & & & \\
\hline Wild-type AtT20 & $\begin{array}{l}637 \pm 88 \\
(n=14)\end{array}$ & \multicolumn{2}{|c|}{$(n=14)$} & $\begin{array}{l}44 \pm 3 \\
(n=14)\end{array}$ & $\begin{array}{c}92 \pm 21 \\
(n=16)\end{array}$ & $\begin{array}{l}6.6 \pm 0.5 \\
(n=14)\end{array}$ \\
\hline Clone R I & $\begin{array}{l}3250 \pm 379^{b} \\
(n=9)\end{array}$ & $\begin{array}{r}183 \pm 19^{b} \\
(n\end{array}$ & $\begin{array}{l}128 \pm 16^{b} \\
9)\end{array}$ & $\begin{array}{l}30 \pm 4^{c} \\
(n=9)\end{array}$ & $\begin{array}{l}160 \pm 17^{d} \\
(n=9)\end{array}$ & $\begin{array}{l}17.8 \pm 2.1^{b} \\
(n=9)\end{array}$ \\
\hline
\end{tabular}

Cells were stepped to $+50 \mathrm{mV}$ from a holding potential of $-90 \mathrm{mV}$. Significance was determined by Student's $t$ test Data are presented as mean \pm SEM.

a Current at end of $300 \mathrm{msec}$ pulse.

${ }^{b} p<0.0005$.

$p<0.005$

${ }^{d} p<0.05$. 
CONTROL AtT-20

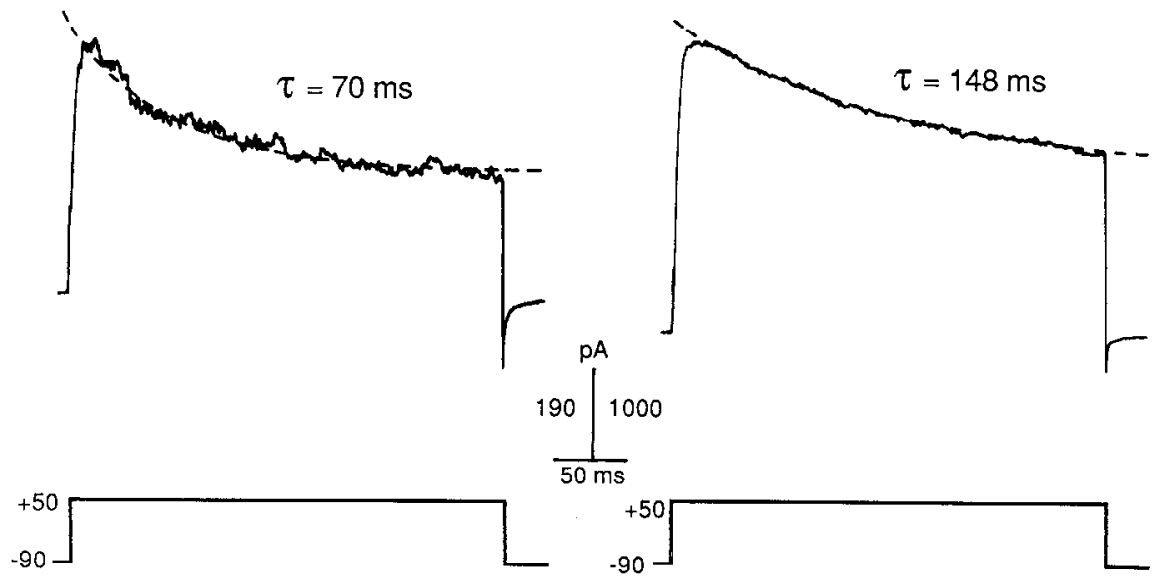

RAS AtT-20

Figure 4. Potassium currents from a normal AtT20 cell (left) and a cell from ras-transfected clone $\mathrm{R} 1$ (right) fitted to curves for a single exponential (broken line). phase of the outward currents could readily be fit to a single exponential curve in both control and ras-transfected cells. This is shown in Figure 4, where the currents evoked by stepping the membrane potential from $-90 \mathrm{mV}$ to $+50 \mathrm{mV}$ for $300 \mathrm{msec}$ have been plotted at the same size for two cells. The time constant of inactivation for the ras-transfected cell is about twice that of the control AtT20 cell. The mean time constants for the two populations of cells are presented in Table 1 . The $I-V$ relationships in Figure $3 B$ show both the peak current and the current recorded at the end of a $300 \mathrm{msec}$ pulse. The decreased amount of inactivation of potassium current in the ras-transfected cells can also be seen in Figure 3. The $I-V$ relationships of the two cells appear similar from $-60 \mathrm{mV}$ to $+10 \mathrm{mV}$. Inactivation becomes apparent at steps more positive than +10 $\mathrm{mV}$. The difference between the peak and final currents increases with depolarization for both cell types. The proportional decrease in current is, however, significantly greater in the control cells than in the ras-transfected cells ( $p<0.005$; Table 1$)$.

\section{ras induces potassium channel $m R N A$ expression}

Experiments were carried out to test whether the change in amplitude and kinetics of potassium current in the ras-transformed cells is associated with an alteration in the type of potassium channel genes expressed or in the level of their expression. PolyA RNA was prepared from control and ras-transfected AtT 20 cells and subjected to Northern blot analysis using cDNA probes derived from mammalian members of each of three subfamilies of the Shaker family of voltage-dependent potassium channel genes. These were the clones Kv1, a member of the Shaker subfamily (Swanson et al., 1990); Kv4, a member of the Shaw subfamily (Luneau et al., 1991); and drk1, a member of the Shab subfamily (Frech et al., 1989). Of the probes used, a positive hybridization signal was detected only with the Kv4 cDNA probe (Fig. 5). Interestingly, only RNA from ras-transfected cells contained transcripts that hybridized. No corresponding signals could be detected in the same amount of RNA from normal AtT20 cells. Probes directed against the rat Kv1 gene or against drk1 revealed no hybridizing transcripts by Northern blot analysis in either the normal or ras-transfected AtT20 cells. Under the same conditions, a hybridization signal for $\mathrm{Kvl}$ could be readily detected in RNA from rat anterior pituitary and GH3 cells (Hemmick et al., 1990; Levitan et al., 1991) and drkl hybridizing sequences were detected in denervated skeletal muscle (J. Trimmer, personal communication).

RNA transcribed from the $\mathrm{Kv} 4$ gene is subject to alternative splicing and can generate two different channel species, the Kv4 channel itself and NGK2, another member of the Shaw subfamily of potassium channels (Yokoyama et al., 1989; Luneau et al., 1991). The sequence of NGK2 is identical to that of the Kv4 gene product over much of the coding region but differs from Kv4 at the carboxyl end of the predicted protein sequence. The sizes of the major transcripts recognized by Kv4- and NGK2specific probes are 4.5 and 7.0 kilobases, respectively (Yokoyama et al., 1989; Luneau et al., 1991). The larger of these two is in good agreement with the size of the major species recognized by the full-length Kv 4 cDNA probe in the ras-transfected AtT20 cells (Fig. 5). In addition, in some experiments, we detected a weaker hybridization signal at $\sim 4.5$ kilobases (not shown).

To establish further whether the $\mathrm{Kv} 4$ gene is expressed in rastransfected cells, and to determine whether its transcript is sclectively processed to yield either the Kv4 or NGK2 mRNAs, we used the technique of ribonuclease protection. For this purpose, we generated an antisense RNA probe that, at its $5^{\prime}$ end, was complementary to 108 nucleotides of sequence common to both Kv4 and NGK2 mRNAs. The 290 nucleotides at the $3^{\prime}$ end of this probe were complementary exclusively to Kv4 mRNA. A ribonuclease protection experiment should result in a 398 nucleotide protected fragment when the probe is hybridized to Kv4 mRNA and in a 108 nucleotide protected fragment when the probe is annealed to NGK2. The results of this experiment are shown in Figure 6. Both products of the Kv4 gene are expressed in rat cerebral cortex (lanes 2,3) where the larger protected band, corresponding to Kv4 mRNA, is the predominant species. No hybridization signal was detected at either size in lanes corresponding to wild-type AtT20 cells (lanes 4, 5, 8). In RNA from the ras-transformed cells, however, there are protected sequences at gel mobilities expected for both $\mathrm{Kv} 4$ and NGK2 mRNAs (lanes 6, 7, 9). Interestingly, there is relatively more NGK 2 expression in ras-transfected AtT20 cells. The predicted band corresponding to NGK2 mRNA appeared to be in approximately sixfold molar excess over that for $\mathrm{Kv} 4$ as determined by scanning densitometry and normalized for the differ- 

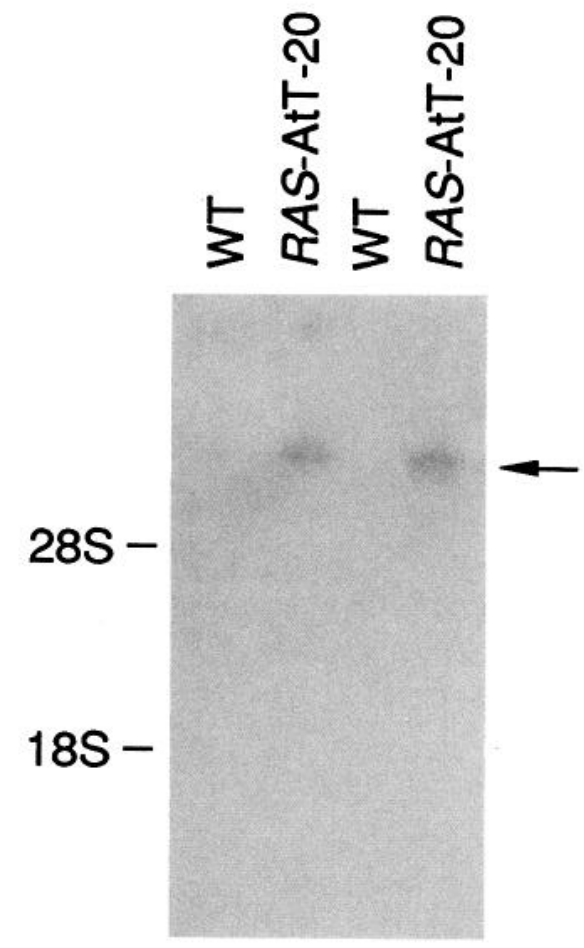

Figure 5. Induction of potassium channel mRNA recognized by Kv4 cDNA in ras-transfected AtT20 cells. RNA preparation and Northern blot hybridization were performed as described in Materials and Methods. Lanes 1 and 2, $5 \mu \mathrm{g}$ of polyA RNA from wild-type (WT) AtT20 cells and clone R1, respectively; lanes 3 and $4,10 \mu \mathrm{g}$ of polyA RNA as in lanes $I$ and 2 , respectively. The mobilities of the $18 \mathrm{~S}$ and $28 \mathrm{~S}$ ribosomal RNA markers, 2.0 and 5.1 kilobases, respectively, are indicated on the left side of the figure. The arrow denotes the bands corresponding to the NGK2 mRNA species.

ences in the number of cytidine residues in each band. Thus, ras appears to induce potassium channel mRNAs corresponding to members of the Shaw subfamily of potassium channel genes.

\section{Discussion}

We have shown that transfection of the EJ-ras oncogene into AtT 20 cells induces a major change in their electrical properties. Ras transfection causes a decrease in the width of spontaneous and evoked action potentials. This is accompanied by an increased density and decreased rate of inactivation of the voltagedependent potassium current, and by the appearance of new mRNA species that encode voltage-dependent potassium channels.

It is likely that the induction of the $\mathrm{Kv} 4$ gene, brought about by ras transfection, results in the synthesis of new potassium channel proteins and contributes to the changes in the characteristics of the potassium currents. The kinetics of the potassium currents in ras-transfected cells do not exactly match those of either Kv4 or NGK2 when these are expressed in Xenopus oocytes. In particular, neither Kv4- nor NGK2-induced currents in oocytes undergo significant inactivation during depolarizations of 200 msec (Yokoyama et al., 1989; Luneau et al., 1991) whereas the currents in ras-transformed cells inactivate with a time constant of $160 \mathrm{msec}$. The protein products of potassium channel genes are, however, believed to form either homo- or hetero-oligomers with each other (Christie et al., 1990; Isacoff

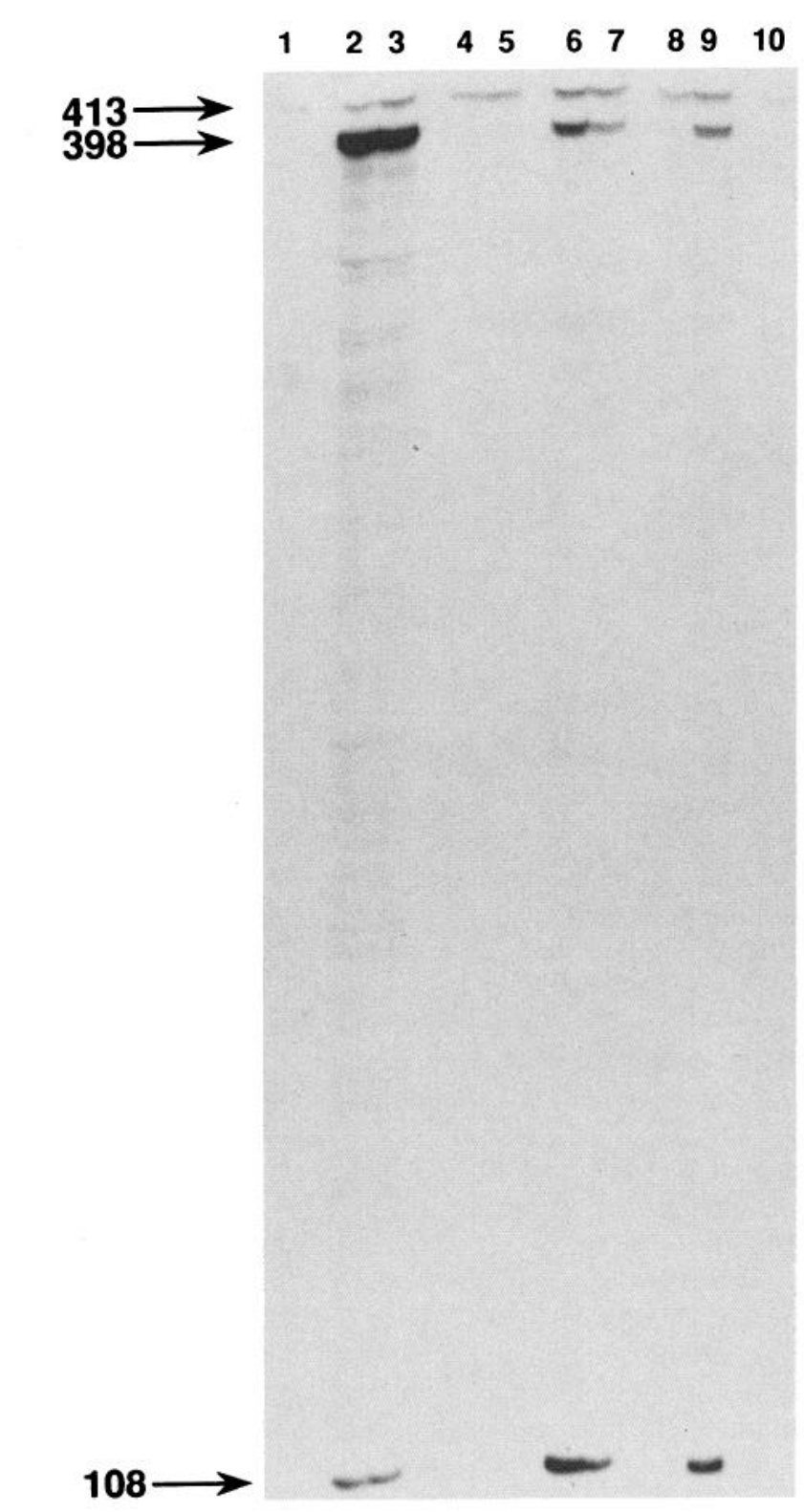

Figure 6. Ribonuclease protection assay for Kv4 and NGK2 mRNAs. Lane $1,30 \mu \mathrm{g}$ of yeast transfer RNA; lanes 2 and 3,30 and $15 \mu \mathrm{g}$ of total RNA from rat cerebral cortex, respectively; lanes 4 and 5, 15 and $30 \mu \mathrm{g}$ of total RNA from normal (wild-type) AtT20 cells, respectively; lanes 6 and 7,30 and $15 \mu \mathrm{g}$ of total RNA from ras oncogene-transformed clone R1, respectively; lanes 8 and $9,1 \mu \mathrm{g}$ of polyA RNA from normal AtT 20 cells and ras-transformed clone R1, respectively; lane 10, 500 cpm of probe. Lanes $1-9$ were digested with $6 \mu \mathrm{g} / \mathrm{ml}$ RNase T1 and 2 $\mu \mathrm{g} / \mathrm{ml}$ RNase A for $1 \mathrm{hr}$ at $34^{\circ} \mathrm{C}$. A small amount of residual undigested full-length 413 nucleotide probe can be detected at the top of the gel. This is due to incomplete removal of the template DNA and is constant in all lanes with or without added RNA and therefore does not interfere with the interpretation of the protected bands.

et al., 1990) or with smaller subunits (Rehm and Lazdunski, 1988). It is possible, therefore, that the currents in ras-transformed cells may result from the formation of heteromultimeric complexes of Kv4 or NGK2 with other channel subunits that coexist in both control and ras-transfected cells. Alternatively, $\mathrm{Kv} 4$ or NGK2 proteins in ras-transfected cells may form homomultimeric channels whose kinetics differ from the oocyte cur- 
rents because of their association with non-Shaker-like proteins found in AtT20 cells or because of posttranslational modifications that do not exist in these oocytes.

Transcription from the Kv4 gene yields two mRNAs, the Kv4 channel species and NGK2, another member of the Shaw subfamily of potassium channels (Luneau et al., 1991). NGK2 was first cloned from NG108-15 cells, a mouse-rat neuroblastomaglioma hybrid cell line (Yokoyama et al., 1989). Its sequence is almost identical to that of the Kv4 cDNA sequence, isolated from rat brain mRNA, over much of the coding region, including all of the hydrophobic presumed membrane-spanning regions that are believed to constitute the voltage sensors and the ion pore itself. It diverges from $\mathrm{Kv} 4$, however, at the carboxyl end, which is predicted to be a cytoplasmic tail (Luneau et al., 1990). The lack of total sequence identity at the $5^{\prime}$ end of the cDNA is possibly due to species variation since $\mathrm{Kv} 4$ is a rat brain clone and NGK 2 was cloned from a mouse rat neuroblastoma-glioma hybrid cell line. The results of Northern blot analysis and ribonuclease protection assays indicate that both forms exist in the ras-transfected AtT20 cells but that the mRNA for NGK2 is found at higher levels than that for the Kv4 channel. No trace of either form could be found in the control cells, and the identity of the potassium channel genes expressed in the untransfected cells is not yet known.

A ras-induced change in the amplitude and kinetics of potassium currents need not occur solely through the synthesis of a new complement of ion channel proteins. It is possible that activated ras proteins produce a posttranslational modification of preexisting or newly induced potassium channels in AtT20 cells, or that such channels interact directly with $\mathrm{p} 21^{\mathrm{ras}}$ and its associated GAP. For example, putative allosteric interactions of an inwardly rectifying potassium channel with the ras-GAP complex occur in isolated membrane patches from guinea pig atrial muscle (Yatani et al., 1990). It is not yet known if such direct effects of the ras protein on the delayed-rectifier potassium channels contribute to the change in amplitude or kinetics of these currents in AtT20 cells.

The ras oncogene-induced transition in the shape of action potentials, which is coupled to a change in morphology to a neuronlike form, resembles the changes in action potentials that occur in many neurons during their development (Spitzer and Lamborghini, 1976; Henderson and Spitzer, 1986), and probably results from changes in more ion currents than we have described here. In a previous report, we found that control At T20 cells express a TTX-insensitive sodium current that accounts for approximately $40 \%$ of the total voltage-dependent sodium current in these cells. After transfection with activated ras, however, this TTX-insensitive current is eliminated (Flamm et al., 1990). The loss of such a current also occurs during the normal development of a number of excitable cells. Preliminary evidence, using calcium-indicator dyes, also suggests that calcium currents may differ in their amplitude and pharmacology in the control and ras-transfected AtT20 cells (N. C. Birnberg and L. M. Hemmick, unpublished observations).

The introduction of the ras oncogene has been shown to alter the characteristics of ionic currents in cell lines other than AtT20 cells, such as $3 \mathrm{~T} 3$ fibroblasts and BC3M1 myocytes (Caffrey et al., 1987; Chen et al., 1988; Rane, 1990). Our studies, in a pituitary cell line, suggest that such changes may occur through the expression of a novel set of ion channel genes. Moreover, because the $\mathrm{Kv} 4$ gene is normally expressed in the nervous system, our results support the hypothesis that a ras protein plays a role in the differentiation of cells to a neuronal-like phenotype.

\section{References}

Adler M, Wong BS, Sabol SL, Busis N, Jackson MB, Weight WW (1983) Action potentials and membrane ion channels in clonal anterior pituitary cells. Proc Natl Acad Sci USA 80:2086-2093.

Ausubel FM, Brent R, Kingston RE, Moore DD, Seidman JG, Smith JA, Struhl K (1990) In: Short protocols in molecular biology, pp 154-155. New York: Wiley.

Barbacid M (1987) Ras genes. Ann Rev Biochem 56:779-827.

Birnberg NC, Stork PJS, Hemmick LM (1992) Expression of the c Harvey ras oncogene alters peptide synthesis in the neurosecretory cell line AtT20. J Biol Chem, in press.

Bourne HR, Sanders DA, McCormick F (1990) The GTPase superfamily: a conserved switch for diverse cell functions. Nature 348:125132.

Burgess TI, Kelly RB (1987) Constitutive and regulated secretion of proteins. Annu Rev Cell Biol 3:243-293.

Caffrey JM, Brown AM, Schneider MD (1987) Mitogens and oncogenes can block the induction of specific voltage-gated ion channels. Science 236:570-573.

Chen C, Corbley MJ, Roberts TM, Hess P (1988) Voltage-sensitive calcium channels in normal and transformed 3 T3 fibroblasts. Science 239:1024-1026.

Chomczynski P, Sacchi N (1987) Single-step method of RNA isolation by guanidinium thiocyanate-phenol-chloroform extraction. Anal Biochem 162:156-159.

Christie MJ, North RA, Osborne PB, Douglass JO, Adelman JP (1990) Heteropolymeric potassium channels expressed in Xenopus oocytes from cloned subunits. Neuron 4:405-411.

Davis LG, Dibner MD, Battey JF (1986) Basic methods in molecular biology, pp 143-146. New York: Elsevier.

Flamm RE, Birnberg NC, Kaczmarek LK (1990) Transfection of activated ras into an cxcitable cell linc (AtT20) alters tetrodotoxin sensitivity of voltage-dependent sodium current. Eur J Physiol 416:120125.

Frech GC, VanDongen AMJ, Schuster G, Brown AM, Joho RH (1989) A novel potassium channel with delayed rectifier properties isolated from rat brain by expression cloning. Nature 340:642-645.

Hamill OP, Marty A, Neher E, Sakmann B, Sigworth FJ (1981) Improved patch-clamp techniques for high resolution current recording from cells and cell-free membrane patches. Eur J Physiol 391:85100.

Hemmick LM, Levitan ES, Saal D, Marshall J, Birnberg NC, Kaczmarek LK (1990) Regulation of the brain Kvl potassium channel gene in pituitary cells. Soc Neurosci Abstr 16:672.

Henderson LP, Spitzer NC (1986) Autonomous early differentiation of neurons and muscle cells in single cell cultures. Dev Biol 113:381387.

Herbert E, Allen RG, Paquette TL (1978) Reversal of dexamethasone inhibition of ACTH release in a mouse pituitary cell line either by growing cells in the absence of dexamethasone or by addition of hypothalamic extract. Endocrinology 102:218-225.

Horn R, Marty A (1986) Muscarinic activation of ionic currents measured by a new whole cell recording method. J Gen Physiol 92:145159.

Isacoff EY, Jan YN, Jan LY (1990) Evidence for the formation of heteromultimeric potassium channels in Xenopus oocytes. Nature 345:530-534.

Levitan ES, Hemmick LM, Birnberg NC, Kaczmarek LK (1991) Potassium channel gene expression is induced by dexamethasone in clonal pituitary cells. Mol Endocrinol 5:1903-1908.

Luneau CJ, Burow SA, Marshall J, Antanavage J, Levitan ES, Smith J, Swanson R, Folander K, Bennet C, Oliva C, Kaczmarek LK, Stein $\mathrm{RB}$, Williams JB (1990) Cloning and expression of Kv4, a rat brain delayed rectifier $\mathrm{K}^{+}$channel cDNA. Soc Neurosci Abstr 16:672.

Luneau CJ, Williams JB, Marshall J, Levitan ES, Oliva C, Smith JS, Antanavage J, Folander K, Stein RB, Swanson R, Kaczmarek LK, Buhrow SA (1991) Alternative splicing contributes to $\mathrm{K}^{+}$channel diversity in the mammalian central nervous system. Proc Natl Acad Sci USA 88:3932-3936.

Mizoguchi A, Ueda T, Ikala K, Shiku H, Mizoguti H, Takai Y (1989) 
Localization and subcellular distribution of cellular ras gene products in rat brain. Mol Brain Res 5:31-44.

Rane SG (1990) A Ca(2+)-activated $\mathrm{K}^{+}$current in ras-transformed fibroblasts is absent from nontransformed cells. Am J Physiol 260: Cl04-C112.

Rehm H, Lazdunski M (1988) Purification and subunit structure of a putative $\mathrm{K}^{+}$channel protein identified by its binding to dendrotoxin I. Proc Natl Acad Sci USA 85:4914-4923.

Roberts JL, Phillips M, Rosa PA, Herbert E (1978) Steps involved in the processing of common precursor forms of adrenocorticotropin and endorphin in cultures of mouse pituitary cells. Biochemistry 17 3609-3618.

Shih C, Weinberg RA (1982) Isolation of a transforming sequence from a human bladder carcinoma cell line. Cell 29:161-169.

Spitzer NC, Lamborghini JE (1976) The development of the action potential mechanism of amphibian neurons isolated in cell culture. Proc Natl Acad Sci USA 73:1641-1645.

Suprenant A (1982) Correlation between electrical activity and ACTH/ $\beta$-endorphin secretion in mouse pituitary tumor cells. J Cell Biol 5: 559-566.

Swanson R, Marshall J, Smith JR, Williams JB, Boyle MB, Folander $\mathrm{K}$, Luneau CJ, Antanavage J, Oliva C, Buhrow SA, Bennet C, Stein RB, Kaczmarek LK (1990) Cloning and expression of cDNA and genomic clones encoding three delayed rectifier $\mathrm{K}^{+}$channels in rat brain. Neuron 4:929-939.

Vogel US, Dixon RAF, Schaber MD, Diehl RE, Marshall MS, Scolnick EM, Sigal IS, Gibbs JB (1988) Cloning of bovine GAP and its interaction with oncogenic ras p21. Nature 335:90-93.

Yatani A, Okabe K, Polakis P, McCormick F, Brown AM (1990) ras p21 and GAP inhibit coupling of muscarinic receptors to atrial $\mathrm{K}^{+}$ channels. Cell 61:769-776.

Yokoyama S, Imoto K, Kawamura T, Higashida H, Iwabe N, Miyata T, Numa S (1989) Potassium channels from NG108-15 neuroblastoma-glioma hybrid cells: primary structure and functional expression from cDNAs. FEBS Lett 259:37-42. 